\title{
Distribution and incidence of Carrot virus $Y$ in Australia
}

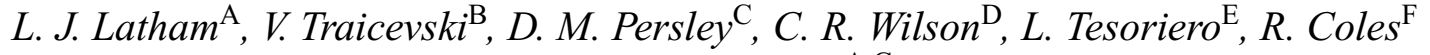 \\ and R. A. C. Jones ${ }^{\mathrm{A}, \mathrm{G}}$

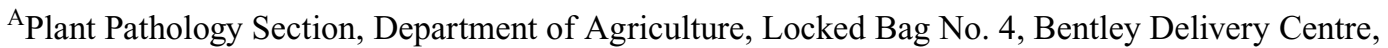 \\ WA 6983, Australia. \\ ${ }^{\mathrm{B}}$ Institute for Horticultural Development, Agriculture Victoria, Private Bag 15, Ferntree Gully Delivery Centre, \\ Vic. 3156, Australia. \\ ${ }^{\mathrm{C}}$ Department of Primary Industries, Queensland Agency for Food and Fibre Sciences (Horticulture), \\ 80 Meiers Road, Indooroopilly, Qld 4068, Australia. \\ ${ }^{\mathrm{D}}$ Tasmanian Institute of Agricultural Research, University of Tasmania, New Town Research Laboratories, \\ 13 Saint Johns Avenue, New Town, Tas. 7008, Australia. \\ ${ }^{E}$ Elizabeth Macarthur Agricultural Institute, New South Wales Agriculture, PMB 8, Camden, NSW 2570, Australia. \\ ${ }^{\mathrm{F}}$ Lenswood Research Centre, South Australian Research and Development Institute, Swamp Road, Lenswood, \\ SA 5240, Australia. \\ ${ }^{\mathrm{G}}$ Corresponding author; email: rjones@agric.wa.gov.au
}

\begin{abstract}
In 2000-2002, Carrot virus Y (CarVY) was found infecting carrot crops in six Australian states. Its occurrence was greater where carrot production was continuous (New South Wales, South Australia, Victoria and Western Australia), than where production was restricted mostly to the summer (Tasmania) or winter (Queensland) months. The percentages of farms and crops infected, respectively, were New South Wales $(71 \%, 56 \%)$, Queensland $(5 \%, 4 \%)$, South Australia $(56 \%, 56 \%)$, Tasmania $(4 \%, 4 \%)$, Victoria $(93 \%, 74 \%)$ and Western Australia $(28 \%$, $19 \%)$. Infection was detected in 30 of 36 carrot cultivars. Possible explanations for the widespread distribution and incidence of CarVY in Australian carrots are discussed.
\end{abstract}

Additional keywords: Daucus carota, potyvirus, surveys, occurrence, prevalence.

\section{Introduction}

In 2000, Australia produced $283000 \mathrm{t}$ of carrots (Daucus carota). The largest carrot-growing state was Victoria (VIC), which produced $\sim 122000$ t. Western Australia (WA) produced $\sim 52000 \mathrm{t}$ and accounted for over $90 \%$ of all carrot exports, selling them to Japan, South East Asia and states in the Persian Gulf. In New South Wales (NSW), South Australia (SA), VIC and WA, carrots are produced all year round. In Tasmania (TAS), which has a cold winter, and Queensland (QLD), which has a hot summer, carrots are produced mainly in the summer and winter months, respectively (Anon. 2002; McKay 2002).

Carrot virus $Y$ (CarVY) is one of three serologically related potyviruses infecting species of Apiaceae in Australia. It has been reported only in this country where it is found only in carrots (Moran et al. 2002; Latham and Jones 2000, 2002, 2004). Celery mosaic virus (CeMV) commonly occurs in celery (Apium graveolens) in Australia (Latham and Jones 2003) and has been found once here in a self-sown, wild carrot. Apium virus Y (ApVY) infects cultivated parsley (Petroselinum crispum) and several apiaceous weed species in Australia. Both CeMV and ApVY are also found overseas. These three viruses form a distinct subgenus within the Potyviridae (Moran et al. 2002).

CarVY is transmitted by aphids in a non-persistent manner and has a narrow natural host range. Foliar symptoms in carrots are a chlorotic mottle, marginal leaf necrosis or reddening and generalised chlorosis, increased subdivision of leaflets giving a 'feathery appearance' and mild plant stunting (Latham and Jones 2002). Carrot roots from plants infected when young are stubby and show severe distortion and knobliness, a symptom combination sometimes known as 'Michelin carrots' (Latham and Jones 2002).

This paper reports the results of surveys to determine the incidence and distribution of CarVY in carrot crops growing in the major carrot-producing regions of Australia and suggests possible reasons for its widespread occurrence. 


\section{Methods}

Glasshouse grown plants

All plants were grown in insect-proof, air-conditioned glasshouses maintained at $15-20^{\circ} \mathrm{C}$. Carrot, cv. Stefano, and celery, cv. Tendercrisp, were grown in a steam-sterilised soil, sand and peat mix (1:1:1).

\section{Virus isolates and inoculations}

Isolates used in WA were CarVY WA-1 from a symptomatic carrot collected at Guilderton, WA (Latham and Jones 2000), and CeMV WA1 described by Latham and Jones (2003). Isolates used in VIC were CarVY WA-1 and CeMV Vic-1. Those used in NSW were freeze-dried CarVY NSW-1 and CeMV NSW-1, in TAS CarVY WA-1 and CeMV Tas-1, while in QLD CarVY WA-1 and CeMV DPI 972 (Moran et al. 2002) were used. CarVY was maintained in carrot by aphid transmission using Myzus persicae. CeMV was maintained in celery by manual inoculation. These cultures of CarVY and CeMV were used as positive controls in enzyme-linked immunosorbent assay (ELISA).

\section{ELISA}

A generic monoclonal antibody specific to most potyviruses was obtained from Agdia Inc., USA and polyclonal antibodies to CeMV were obtained from DSMZ GmbH, Germany. To test for potyviruses using the generic potyvirus monoclonal antibody, leaf samples were extracted in $0.05 \mathrm{~m}$ sodium carbonate buffer $\mathrm{pH} 9.6(1-2 \mathrm{~g}$ leaf $/ 20 \mathrm{~mL})$ and tested using the antigen-coated indirect ELISA protocol of Torrance and Pead (1986). To test for infection with CeMV, samples were extracted in phosphate-buffered saline $(10 \mathrm{~mm}$ potassium phosphate, $150 \mathrm{~mm}$ sodium chloride), $\mathrm{pH} 7.4$, containing $0.5-5 \mathrm{~mL} / \mathrm{L}$ of Tween 20 and $20 \mathrm{~g} / \mathrm{L}$ of polyvinyl pyrrolidone and tested with CeMV specific polyclonal antibodies using double antibody sandwich ELISA (Clark and Adams 1977). With both types of ELISA, each sample extract and appropriate controls were tested in duplicate wells of a microtitre plate. The substrate used was $0.6 \mathrm{mg} / \mathrm{mL}$ of $p$-nitrophenyl phosphate in $100 \mathrm{~mL} / \mathrm{L}$ of diethanolamine buffer, $\mathrm{pH}$ 9.8. Absorbance values $\left(\mathrm{A}_{405 \mathrm{~nm}}\right)$ were measured in a Multiskan plate reader (Labsystems, Finland) and values more than twice those of healthy leaf sap were considered positive.

\section{Field surveys of carrot crops}

During 2000-2002, carrot crops that were close to harvest were surveyed for CarVY (Table 1). For each crop, 100 young shoots were sampled (one shoot per plant) at intervals of $\sim 3 \mathrm{~m}$ down several crop rows. Initially, samples were always tested in groups of ten using both the potyvirus monoclonal antibody and the CeMV polyclonal antibody. Except with those from Victoria, samples were re-tested in smaller groups or individually when the incidence of infection was high. For this retesting, generic potyvirus and CeMV specific antibodies were both used, except in QLD and NSW, where only the CeMV antibodies were used. Percentage virus incidence was estimated from grouped sample test results using the formula of Gibbs and Gower (1960).

\section{Results}

\section{Differentiation of CarVY from CeMV}

After $1 \mathrm{~h}$ of incubation at room temperature, extracts from CarVY-infected carrot leaves (control isolates) gave ELISA absorbance values $\left(\mathrm{A}_{405 \mathrm{~nm}}\right)$ that were 10-40 times greater than that of the healthy carrot control with the generic potyvirus antibody, but only 5-15 times greater than that of the healthy carrot control with the CeMV antibodies. Extracts from CeMV-infected celery leaves (control isolates) gave absorbance values $\left(\mathrm{A}_{405 \mathrm{~nm}}\right)$ that were 50-90 times greater than that of the healthy celery control with the generic potyvirus antibody and 40-120 times greater than that of the healthy celery control with the CeMV antibodies. Extracts from naturally infected carrot samples had absorbance values $\left(\mathrm{A}_{405 \mathrm{~nm}}\right)$ which were 10-90 times greater than that of the healthy carrot control with the generic monoclonal potyvirus antibody, and 9-15 times greater than that of the healthy carrot control with the CeMV polyclonal antibodies. The weakness of the reactions observed with the CeMV antibodies relative to those observed with the generic potyvirus monoclonal antibody suggest that all ELISA positive samples collected in our surveys were CarVY.

\section{Surveys}

In WA, CarVY was found in carrot crops in northern and southern metropolitan Perth and Myalup, but not at Augusta (Fig. 1; Table 1). Incidences of infection in most affected crops were $1-2 \%$ but on two carrot export farms in the Guilderton region, they exceeded 50\% in 11 crops. In VIC, CarVY was detected in crops in all five carrot-growing regions (north-western irrigation, northern irrigation, Port Phillip, south Gippsland and central Gippsland). In SA, CarVY was detected in six carrot-growing regions (Blanchetown, Kybybolite, Mount Gambier, Nuriootpa, Virginia and Waikerie) but not at Parilla. Incidences of infection in production crops were from 1 to $11 \%$, but were as high as $98 \%$ in seed crops at Binnum. In NSW, carrot crops were surveyed only in the Murrumbidgee irrigation region where incidences in infected crops were $2-100 \%$. In

Table 1. Occurrence of CarVY in carrots in six Australian states

\begin{tabular}{|c|c|c|c|c|c|c|}
\hline State & Seasons when crops sampled & $\begin{array}{c}\text { Number of } \\
\text { farms surveyed }\end{array}$ & $\begin{array}{l}\% \text { farms where } \\
\text { infection found }\end{array}$ & $\begin{array}{c}\text { Number of } \\
\text { crops sampled }\end{array}$ & $\begin{array}{l}\% \text { crops } \\
\text { infected }\end{array}$ & $\begin{array}{l}\text { Range of infection in } \\
\text { infected crops }(\%)\end{array}$ \\
\hline New South Wales & Autumn, winter, spring & 7 & 71 & 25 & 56 & $2-100$ \\
\hline South Australia & Autumn, winter, spring, summer & 25 & 56 & 25 & 56 & $1-98$ \\
\hline Victoria & Winter, spring, summer & 16 & 93 & 54 & 74 & ND \\
\hline Western Australia & Spring, summer, autumn & 18 & 28 & 67 & 19 & $1-95$ \\
\hline Queensland & Winter, early spring & 20 & 5 & 27 & 4 & 1 \\
\hline Tasmania & Summer, early autumn & 25 & 4 & 25 & 4 & 3 \\
\hline
\end{tabular}

$\mathrm{ND}=$ not determined 


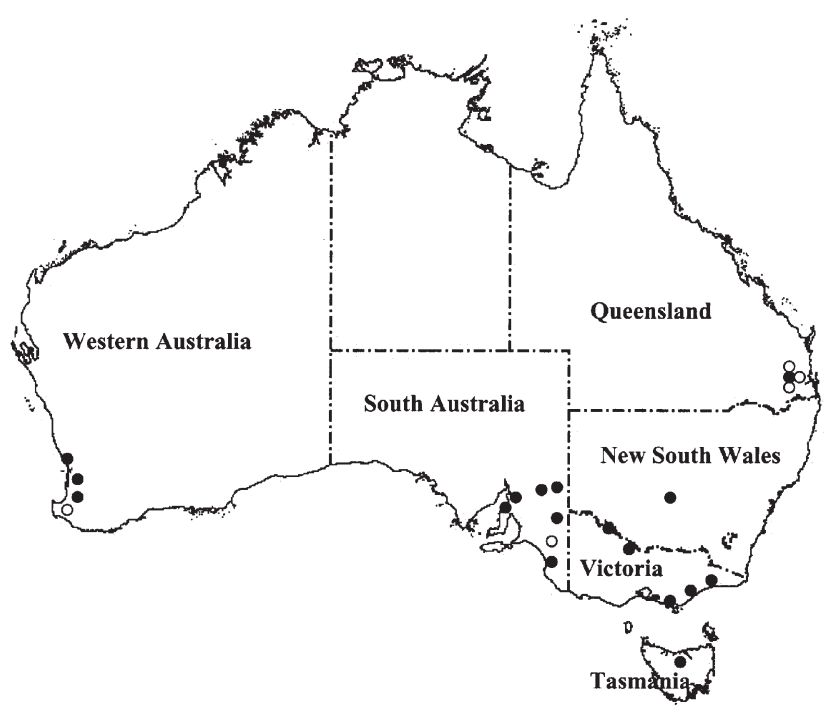

Fig. 1. Locations where carrots were surveyed CarVY found; $O=$ no CarVY found).

QLD, carrot crops were surveyed in the Fassifern, Granite Belt, Lockyer Valley and southern Darling Downs regions. CarVY was found in only one crop in the southern Darling Downs, with an incidence of $1 \%$. In TAS, CarVY was found in only one crop at Forth, with an incidence of $3 \%$.

CarVY was detected in 30/36 cultivars (Table 2). In WA, cv. Stefano was the most frequently surveyed and 20/61 crops of this cultivar were found infected. In VIC, cvv. Stefano and Mokum were the most frequently surveyed, with 13/15 and 3/9 crops infected, respectively. In SA, cvv. Carisma, Ricardo and Stefano were most frequently surveyed, with $1 / 2,1 / 5$ and $2 / 3$ crops of each infected, respectively. In NSW, cvv. Western Red, All Seasons and Kamaran were the most frequently surveyed, with $5 / 5,2 / 3$ and $1 / 3$ crops infected, respectively. All but one of the carrot crops surveyed in QLD were of cv. Stefano, including the one infected crop. Senior, Coral II and Stefano were the predominant cultivars surveyed in TAS but only cv. Senior was infected.

\section{Discussion}

In the absence of CarVY-specific antibodies during this study, we used CeMV-specific antibodies to detect CarVY in our surveys, as the two viruses are serologically related. However, we have confidence that we were detecting only CarVY and not CeMV in the carrot crops for several reasons. Firstly, all records to date indicate that cultivated carrots in Australia are naturally infected only with CarVY and not CeMV (Moran et al. 2002). Secondly, the ELISA positive carrot samples from diverse origins collected by us always reacted weakly with the CeMV antibodies but strongly with the potyvirus monoclonal antibody. The weak reactions between CeMV antibodies and positive carrot samples
Table 2. Detection of CarVY in different carrot cultivars ${ }^{\mathrm{A}}$

\begin{tabular}{|c|c|c|}
\hline Cultivar & $\begin{array}{l}\text { Numbers of crops with positive } \\
\text { samples/numbers tested }\end{array}$ & $\begin{array}{l}\text { Incidences of } \\
\text { infection (\%) }\end{array}$ \\
\hline All Seasons & $2 / 3$ & $0-85$ \\
\hline Bangor & $1 / 1$ & 47 \\
\hline Bastille & $4 / 4$ & $2-12$ \\
\hline Cameron & $1 / 1$ & 100 \\
\hline Carisma & $1 / 2$ & $0-2$ \\
\hline CLX3161 & $1 / 1$ & 1 \\
\hline Coral II & $0 / 12$ & 0 \\
\hline Crusader & $13 / 15$ & $0-76$ \\
\hline Havana & $3 / 3$ & $1-7$ \\
\hline Ivor & $0 / 4$ & 0 \\
\hline Jarit & $1 / 1$ & 1 \\
\hline Kamaran & $1 / 3$ & $0-1$ \\
\hline Kendo & $1 / 4$ & $0-9$ \\
\hline Koуо II & $2 / 2$ & $25-40$ \\
\hline Leonore & $1 / 1$ & $\mathrm{ND}^{\mathrm{B}}$ \\
\hline Mojo & $4 / 5$ & ND \\
\hline Mokum & $3 / 9$ & $0-2$ \\
\hline Murdoch & $4 / 8$ & $0-52$ \\
\hline Nigel & $1 / 1$ & 1 \\
\hline Nairobi & $0 / 3$ & 0 \\
\hline Omeros & $2 / 2$ & $3-5$ \\
\hline Ostende & $1 / 1$ & ND \\
\hline Paris & $2 / 4$ & $0-32$ \\
\hline Red Cloud & $0 / 2$ & 0 \\
\hline Red Count & $0 / 1$ & 0 \\
\hline Red Hot & $1 / 3$ & $0-11$ \\
\hline Red Sabre & $1 / 1$ & ND \\
\hline Red Victor & $1 / 1$ & ND \\
\hline Ricardo & $3 / 9$ & $0-4$ \\
\hline Senator & $0 / 2$ & 0 \\
\hline Senior & $4 / 11$ & ND \\
\hline Stefano & $38 / 109$ & $0-95$ \\
\hline Sun Star & $1 / 2$ & $0-11$ \\
\hline Victor & $1 / 1$ & 2 \\
\hline Viking & $1 / 1$ & 1 \\
\hline Western Red & $5 / 5$ & $1-5$ \\
\hline Kuroda type & $1 / 3$ & 0-98 \\
\hline Nantes type & $1 / 1$ & $0-45$ \\
\hline Unknown & $2 / 8$ & $0-10$ \\
\hline
\end{tabular}

${ }^{\mathrm{A}} 100$ samples were collected per crop and tested for CarVY by ELISA to determine per cent infection.

${ }^{\mathrm{B}} \mathrm{ND}=$ not determined.

contrasted with those observed with the CeMV control isolates. Independent verification that the naturally infected carrot samples from the surveys contained CarVY was obtained in two ways. Firstly, two survey isolates from WA, one from VIC and four from SA gave strong positive values in ELISA with CarVY-specific antibodies from DSMZ that became available after the surveys were completed (L. J. Latham, L. J. Smith and R. A. C. Jones, unpublished). Secondly, four virus isolates from our carrot surveys were sequenced by Moran et al. (2002), who confirmed them to be CarVY. ApVY, which is reported to infect carrots in Europe 
(Kusterer et al. 2002), does not cross-react with CeMV antibodies in ELISA (Latham and Jones 2003), thus excluding confusion between ApVY and CarVY in our surveys.

CarVY was detected in carrot crops in all six Australian states surveyed and in 17 different carrot-growing regions. Infection was found in 30/36 cultivars. Incidences of CarVY infection in NSW and SA, where carrots are grown continuously throughout the year, were often high, sometimes exceeding 90\%. Such high incidences are also found in VIC (Traicevski et al. 2001). The highest incidences of infection were on farms where carrot production was intensive with carrot plantings sown close to one another throughout the year. Incidences of infection in WA were generally low, except on two large export carrot farms where they were greater than $50 \%$. These two farms practice continuous production under irrigation whereas other farms in the state usually rotate carrots with other crops under irrigation and have sufficient space to sow new crops at large distances from old ones. In QLD and TAS, where carrots are grown for only 6 months of the year, infection did not exceed $3 \%$. Crops for seed production are usually grown for 2 years, which provides a greatly extended period for additional virus spread. The two carrot seed crops tested in our surveys had very high incidences of CarVY infection.

These findings suggest that a break in carrot production can greatly diminish the extent of virus carryover between carrot crops. Short of such a drastic approach at sites where carrots are produced all year round, the best control strategy is through phytosanitary and cultural control measures using integrated disease management tactics (Latham and Jones 2004).

The reason for the occurrence of CarVY infection in carrot crops in isolated and climatically diverse production regions throughout Australia is unknown. Seed transmission and contamination of commercial seed stocks of carrots provides one possible explanation. Preliminary studies suggest that CarVY may be seed-borne in carrot but at very low levels (Latham and Jones 2004). Such seed transmission might also sometimes occur in alternative apiaceous hosts. Another possible explanation is presence of infection reservoirs within alternative hosts belonging to certain introduced apiaceous weeds, native Australian apiaceous plants or other apiaceous crop plants These could provide sources for spread when carrot crops are first introduced to new areas. Further investigations into the seed transmissibility of CarVY and studies to determine if there are alternative infection reservoirs are underway.

\section{Acknowledgements}

We thank Christine Woods, Fiona Bertus, Judith Parry, Andrew Watson, Lisa Whelan and Annabel Wilson for technical support. Horticulture Australia Ltd funded the surveys.

\section{References}

Anon. (2002) Australian Bureau of Statistics. Available online at http://www.abs.gov.au

Clark MF, Adams AN (1977) Characteristics of the microplate method of enzyme-linked immunosorbent assay for the detection of plant viruses. The Journal of General Virology 34, 475-483.

Gibbs AJ, Gower JC (1960) The use of a multiple transfer method in plant virus transmission studies-some statistical points arising from the analysis of results. The Annals of Applied Biology 48, 75-83.

Kusterer A, Rabenstein F, Gabler J, Kuhne T (2002) Occurrence of apium potyvirus $\mathrm{Y}$ and carrot red leaf luteovirus (CRLV) in dill and other umbelliferous plant species. In 'VIIIth International plant virus epidemiology symposium'. Aschersleben, Germany, 12-17 May 2002. p. 95. (Abstr.) (Federal Centre for Breeding Research on Cultivated Plants: Aschersleben, Germany)

Latham LJ, Jones RAC (2000) Yield and quality losses in carrots infected with carrot virus Y. In 'Proceedings and abstracts of Carrot Conference Australia'. Perth, 24-28 October 2000. (Eds E Davison, A McKay) p. 48. (Abstr.) (Department of Agriculture: South Perth, WA)

Latham LJ, Jones RAC (2002) Carrot Virus Y. In 'Compendium of umbelliferous diseases'. (Eds M Davis, R Raid) p. 53. (American Phytopathological Society Press: Minnesota, USA)

Latham LJ, Jones RAC (2003) Incidence of Celery mosaic virus in celery crops in south-west Australia and its management using a celery-free period. Australasian Plant Pathology 32, 527-531.

Latham LJ, Jones RAC (2004) Carrot virus Y: symptoms, losses, incidence, epidemiology and control. Virus Research (in press).

McKay A (2002) The WA export carrot industry. Western Australian Grower 34, 6-12.

Moran J, van Rijswijk B, Traicevski V, Katijima EW, Mackenzie AM, Gibbs AJ (2002) Potyviruses, novel and known in cultivated and wild species of the family Apiaceae in Australia. Archives of Virology 147, 1855-1867. doi:10.1007/S00705-002-0865-8

Torrance L, Pead MT (1986) The application of monoclonal antibodies to routine tests for two plant viruses. In 'Developments in applied biology. 1. Developments and applications on virus testing'. (Eds RAC Jones, L Torrance) pp.103-118. (Association of Applied Biologists: Wellesborne, UK)

Traicevski V, van Rijswijk B, Rowles A, Ziehrl A, Rundle B, Moran J (2001) 'HRDC Project VG97103 - management of celery mosaic virus.' Final Report to Horticulture Australia Ltd, Institute for Horticultural Development Agriculture Victoria, Knoxfield, Victoria.

Received 14 November 2003, accepted 14 August 2003 